\title{
Using remotely sensed data to identify areas at risk: a case of central Slovenia
}

\author{
M. J. Auflič \& M. Komac \\ Geological Survey of Slovenia, Slovenia
}

\begin{abstract}
People have lived with hazards since the dawn of the human race. Humanity has never (and nowhere) been fully safe against natural hazards. Hence the gathering of knowledge about these dangerous phenomena and the urgency to understand them is a necessity. Different natural or human factors have triggered numerous landslides and have caused considerable economic losses over the last 20 years in Slovenia. Traditional methods used for mapping and monitoring mass movements can benefit from the application of remote sensing techniques coupled with GIS analysis. The use of remote sensing technologies, whether airborne, satellite or ground based allows a rapid acquisition of quantitative data over wide areas, reducing the field work and, as a consequence, the costs. Very useful among others is a satellite radar interferometry method of Persistent scatters (PSI) which enables very accurate component surface deformation velocity monitoring in the line-of-sight. This paper discusses the use of multiple image sets of SAR data acquired by past and current satellite platforms for monitoring landslides. Based on interferometric data the areas with slow ground motion will be identified and risk to the inhabitants on the tested area will be assessed based on the landslide hazard map.
\end{abstract}

Keywords: persistent scatterers' interferometry, slow slope movements, hazard, Slovenia.

\section{Introduction}

Landslides are recognized as the third type of natural disaster in terms of worldwide importance [1]. Due to natural conditions or man-made actions, landslides have produced multiple human and economic losses [2] and Slovenia is no exception in this regard. In the past several years, the damaged caused by 
landslides summed to over 2 million $€$ per year [3]. In Slovenian territory mostly shallow landslides and soil slips that occur after short or long lasting rainfall prevail. A very common slope process is also slope creeping. Slope creeping is a pre-failure phenomenon in slopes. In this regard creep means slow movements of slopes due to shrink-swell and freeze-thaw, re-activation of movement of landslides or creep in over-consolidated clays in undrained loading as shear deformations cause dilation and development of negative pore pressures, which do not develop uniformly throughout the sample, but concentrate along planes where the greatest shearing stresses develops [4]. In general, creeping slopes can be categorized either as shallow or as deep seated. Shallow landslides have a vertical extent up to a few meters and horizontal extent up to a few hundred square meters. Formation of shallow landslides mostly occurs in response to extreme rainfall events [5] and depends on near surface structures and processes. Deep seated landslides on the other hand have a vertical extent up to several tens of meters and spread horizontally from a hundred to a few thousand square meters. They are distinguished into fast moving and creeping landslides. Creeping landsides move several centimetres or decimetres per year [6]. Velocity of sloping slides varies between 1 and $10 \mathrm{~cm}$ per year so that the movements do not create visible problems to the buildings and roads on the surface. Short-term landslide triggers are heavy rainfall events, vadose zone and groundwater flows, and pressure dynamics, but they can also include river bank or hill foot erosion during flood events, depending on site conditions. Long-term landslide triggers include seasonal changes of the self-load, due to seasonal soil moisture variations and snow cover, and the contribution of trees and infrastructure to the self-load. Although creeping, deep seated landslides appear less spectacular than the active landslides, in the long term they cause steadily increasing damage to buildings and infrastructure.

Landslides occur very frequently in Slovenia. One quarter of the territory is very subject to sliding [7]. The study of such problems represents a challenge for the professionals. Nowadays, in view of preventing such occurrences are remote sensing and geographic information systems methods almost indispensable source of information on inevitable tool. Only understanding the dynamics of slow movements and using appropriate methods can produce sufficient quality and accurate forecasts. Their prime aim is to reduce or prevent unwanted effects on population and nature.

Many satellites are becoming more and more sophisticated and more capable. The great advantage of data acquired by satellites is that no physical contact is needed and that the data is constantly being collected. Various upgrades of radar interferometry technique, including persistent scattering radar interferometry (PSInSAR), enable monitoring and especially identifying slope instability worldwide. The persistent scatterers' interferometry (PSI) enables to detect the stability/instability for very large areas with a millimetric precision, and a possibility to see historical events at relatively low cost. Its utility gets a high value in areas where other techniques (i.e. visual remote sensing techniques) for monitoring the instability cannot get data. Often PSI is used complementary with other techniques (e.g. ground control point). In the field of engineering geology 
using radar data is not that common. But the ability of PSI method to accurately measure the movements in range of $\mathrm{mm}$ displacements increases its applicability. Many researchers [8-12] already used PSI data in their research to monitor slow slope movements and on that basis they also determined risk.

The main goal of landslide hazard and risk studies is to protect the population, infrastructure and the environment against potential damage caused by landslides [13]. Risk in this context, is seen as a disaster that could happen in the future. The total risk map could be derived directly by combining the hazard and the vulnerability maps. Also specific risk maps can be created and consequences analyzed in order to achieve some preliminary conclusions. At the moment the classification is based on the level of quantification dividing the landslide risk assessment methods in qualitative, semi-qualitative and quantitative.

The paper is focused on the issue of applicability of PSI technique for the determination of creeping zones in the Škofjeloško-Cerkljansko area in central western Slovenia. Due to lack of data (incomplete landslide database, return period of landslide occurrence, potential damage, elements at risk, and social impact on inhabitants) the hazard to the inhabitants and infrastructures (buildings) for the tested area will be assessed based solely on the landslide hazard map.

The method is applied to the Škofjeloško Cerkljansko area that belongs to a perialpine region. This study area was selected due to its highly diverse morphology and numerous historical landslide records. In addition the high presence of clay component in lithological units influences the stability of slopes that are often more subjected to creeping than lithological units without the clay content.

\section{Study area}

The research area is located in the western central part of Slovenia, northwest of Ljubljana, and it occupies approximately $640 \mathrm{~km}^{2}$ (Fig. 1a). The detailed study area marked with black polygon represents $3 \mathrm{~km}^{2}$ (Fig. 1b). Škofjeloško Cerkljansko area has a complex geological structure, constituted of Carboniferous and Permian (shales and quartz sandstones), Permian (quartz conglomerates, sandstones and shales), Triassic (dolomite and limestone, pseudozilian formation - dark grey claystones with green tuff and tuffite and sandstones intercalations), Jurassic and Cretaceous (shaly claystones and marlstones) and fluvial sediments in valleys dating from the Quaternary period. More detailed lithological settings represent Figure 1b.

The area is characterized by a number of settlements, very diverse morphology that reflects several geodynamic processes, active tectonics with numerous faults and thrusts, which produce a complex ground deformation pattern. These factors make the studied area particularly exposed to landslide risk. 
a)

b)

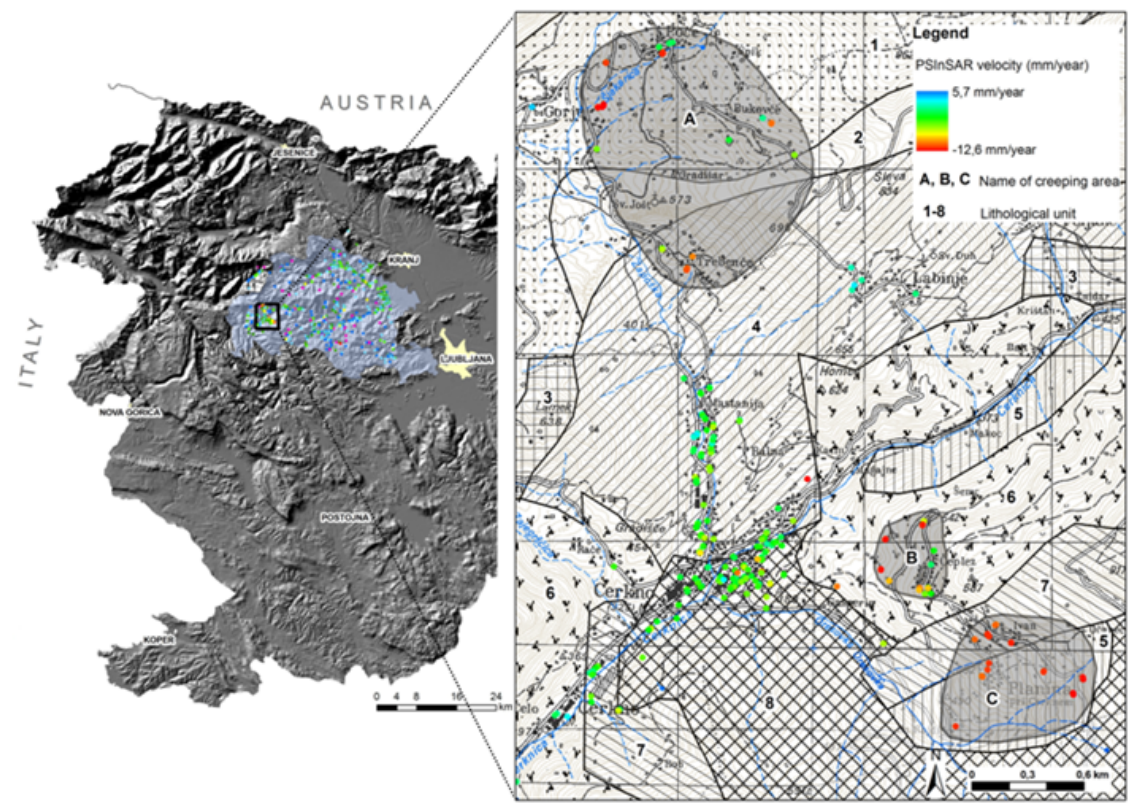

Figure 1: $\quad$ Map showing the location of the study area (a), permanent scatterer points and a detailed map with creeping zones and lithology (b). Creeping zones defined by PSInSAR are marked with bold capital letter (A - area above Cerkno, B - Čeplez, C - Planina). Lithological units are marked with numbers: 1-Alternation of claystone and sandstone, platy limestone in the upper partAmphiclina beds (Upper Triassic-Carnian), 2-Massive coarse crystalline dolomite and limestone (Upper Triassic-Cordevol), 3-Keratophyre, quartz keratophyre, porphyre, porphyrite and their tuffs (Middle Triassic-Ladinian), 4-Shale, siltstone, platy limestone with chert, marlstone, greywacke, sandstone, conglomerate, breccias, tuff - Pseudozilian beds (Middle Triassic-Ladinian), 5-Red and gray sandstone, shale and conglomerate (Middle Permian), 6-Dolomite, micaceous siltstone, claystone, oolitic limestone and dolomite, marlstone, marly limestone (Lower Triassic), 7-Thick bedded dolomite, subordinately limestone (Upper Permian), 8-Alternation of shale and quartz sandstone, quartz conglomerate (Upper Carboniferous and Lower Permian). 


\section{Methodology}

\subsection{Persistent scatterer technique}

The persistent scatterer interferometry (PSI) represents an upgrade of the Interferometric Synthetic Aperture Radar (InSAR) technique and allows users to estimate a deformation time-series for regions that are traditionally considered decorrelated under conventional InSAR techniques. Traditional landslide monitoring techniques are expensive and time consuming. Differential satellite interferometric synthetic aperture radar (DInSAR) is an invaluable tool for land displacement monitoring, particularly for the slow and very slow landslides [14]. Improved access to archived satellite data has led to the development of several innovative multitemporal algorithms, including PSI techniques.

The PSInSAR ${ }^{\mathrm{TM}}$ (Permanent Scatterers Interferometry Synthetic Aperture Radar) that we used in our study was developed by the Politecnico di Milano (POLIMI) in 1999 [15] and latter registered as a trade mark of Tele-Rilevamento Europa. It is based on a multi-interferogram approach. In particular, this technique involves the interferometric phase comparison of several radar images of the same scene (a portion of the Earth surface of $100 \times 100 \mathrm{~km}$ width) taken at different time along the same orbit by the satellite radar sensors. ERS 1 and ERS 2 satellites orbits are at an elevation of $780 \mathrm{~km}$ and acquire image of the same area every 35 days. The critical deformation rate that can be detected is $2.8 \mathrm{~cm}$ in 35 days or $0.8 \mathrm{~mm}$ in a day. This means that from the perspective of slope mass movement kinematics PSI can only detect slow deformation rates, i.e. creeping. The radar detector scans looks to the right of the flight path (west for descending imaging geometry) with an incidence angle of approximately $23.5^{\circ}$ from the vertical. Accuracy of PSI technique depends on the number of radar images used in processing. In order to obtain good results as a minimum about 20 images are required. Not all the acquired images are suitable for interferometric analysis, so that the time interval between two consecutive images can be longer. The radar is only sensitive to the displacement changes line-of-sight (LOS). Applicability of conventional interferometric synthetic aperture radar (InSAR) for crustal deformation studies is limited by the fact that almost any interferogram includes large areas where the signals decorrelate and no reliable measurement is possible. PSI overcomes the decorrelation problem by identifying resolution elements whose echo is dominated by a single scatterer (PS) in a series of interferograms. Combining information from multiple interferograms also mitigates the effect of atmospheric distortions in the deformation estimates. The processing technique is based on the identification of the radar benchmarks, named Persistent Scatterers (PS), which are stable natural or man-made reflectors (Fig. 2) (rock outcrops, buildings and urban structures), characterized by stable individual radar bright and radar phase over long temporal series of interferometric SAR images. Persistent Scatterers can be detected on the basis of a statistical analysis on the amplitudes of their electromagnetic returns [15]. This technique has been proved useful at exploring slow movements of the earth surface, induced by natural and man-induced phenomena such as land 

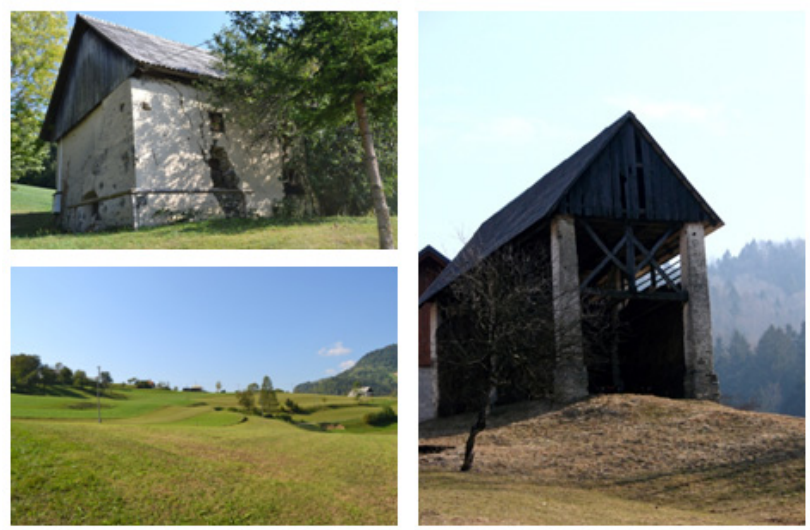

Figure 2: $\quad$ Examples of natural target (PS points) in Škofjeloško Cerkljansko area.

subsidence, landslides, seismic faults, and tectonic deformations, with very high spatial resolution, both at a local and at a regional scale $[9,16,22]$.

In total, 67 ERS scenes acquired between 1992 and 2000 along descending orbits (track 79, frame 2673) were used for the interferometric and statistical analyses of the Škofja Loka and Cerkljansko area. 2787 PS were identified, which correspond to outcrops and man-made structures such as building, poles, and antennas. The geocoding accuracy of the PS locations was around $\pm 15 \mathrm{~m}$ east-west and $\pm 4 \mathrm{~m}$ in the north-south direction, while the estimated accuracy of the elevation values was usually better than $2 \mathrm{~m}$. The line of sight direction displacement rates vary from +7.26 to $-18.75 \mathrm{~mm} / \mathrm{yr}$ and are relative to a reference point located in the town Železniki, which is assumed motionless $\left(46^{\circ} 13^{\prime} 29.13^{\prime \prime} \mathrm{N}, 14^{\circ} 10^{\prime} 31.77^{\prime \prime} \mathrm{E}\right)$. For each acquisition date each PS also has a record, a value of its displacement from the previous acquisition in relation to motionless reference point.

\subsection{Process to determine unstable slopes}

In the research area PS are mostly related to man-made objects such as residential houses, buildings, power-line, sometimes hayracks or an old granary (Fig. 2). Phase shift is highly dependent on the time correlation that can be eliminated in the case of sufficient radar images. When the PS represents building it is important that building has not been restored or the roof was not replaced in the period of monitoring, that is between 1992 and 2000. In case of restoration the PS measurements can be misleading. To avoid such cases we checked all PS located on buildings. The database of cadastral data shows that the replacement of the roof was carried out at 201 buildings [17]. These buildings were not considered in further analysis. Also, 723 PS with unknown position in the field were excluded. Another selection criterion is coherence, a physical value that defines the consistency of reflected/back-scattered radar 
signal through time. Lower coherence value means lower reliability of accuracy of PS data and higher coherence value represents higher reliability. For the whole given area (Fig.1a), the coherence values range from 0.58 to 0.96 . Regarding the coherence of PS data and the reliability of the measured movements, the PS population was divided into two groups: a) a group where the coherence value was lower than 0.60 , and b) a group where the coherence value was between 0.60 and 0.96 [18]. PS points with coherence values lower than 0.60 (311 PS points) were not considered in further analysis due to the assumption that the phase shifts of these points can be a cause of excessive atmospheric effect. Therefore, PS with lower coherence values doesn't represent sufficient reliability for the interpretation. Altogether, 2296 PS were considered to define unstable areas.

\subsection{Landslide susceptibility model}

Landslide susceptibility model for the study area was developed by Komac (2006) [19]. The model was created with a combination of spatial and satellite data using appropriate statistical analysis. Based on the statistical results several landslide susceptibility models were developed using the Analytical Hierarchy Process method (AHP). These models gave very different results, with a prediction error ranging from $4.3 \%$ to $73 \%$.

\section{Results and discussion}

For defining creeping zones the knowledge of local terrain characteristics is very important as well the spatial-temporal factors that influence the creeping. According to the fact that slope creep can be pre-phase of a landslide occurrence, we analysed spatial-temporal factors that play important role in landslide occurrence [7] (slope inclination, slope curvature, slope aspect, land-cover type, and lithology). To identify creeping or landslide zones we performed a correlation between velocities of PS data and slope inclination separately for each lithological unit (Fig. 3). It should be noted that in case of slope creeping the slope failure may occur several years after the initiation of movements. In the regions with a humid climate the slope creeping starts at slopes with $10-15^{\circ}$ and the displacement rates range from 1 to $2 \mathrm{~mm}$ per year while in the regions with a semi humid climate the displacement rates range between 5 and $10 \mathrm{~mm}$ per year [20].

As can be seen from Figure 3, correlations between velocity and slope depend on local terrain characteristic, to some extent on lithology, but also influenced by other factors. Linear correlation between slope and velocity is poorly expressed even when PS are divide into small groups (regarding the lithological units). Correlation coefficients (r) for groups within lithological units in the present case (Fig 3) don't exceed the value \pm 0.48 . This indicates that displacements rates or velocities of PS are not in linear proportions neither with the slope inclination, neither with the lithology, but are rather influenced by a complex combination of several factors. Movement rates don't clearly increase with the increase of slope 

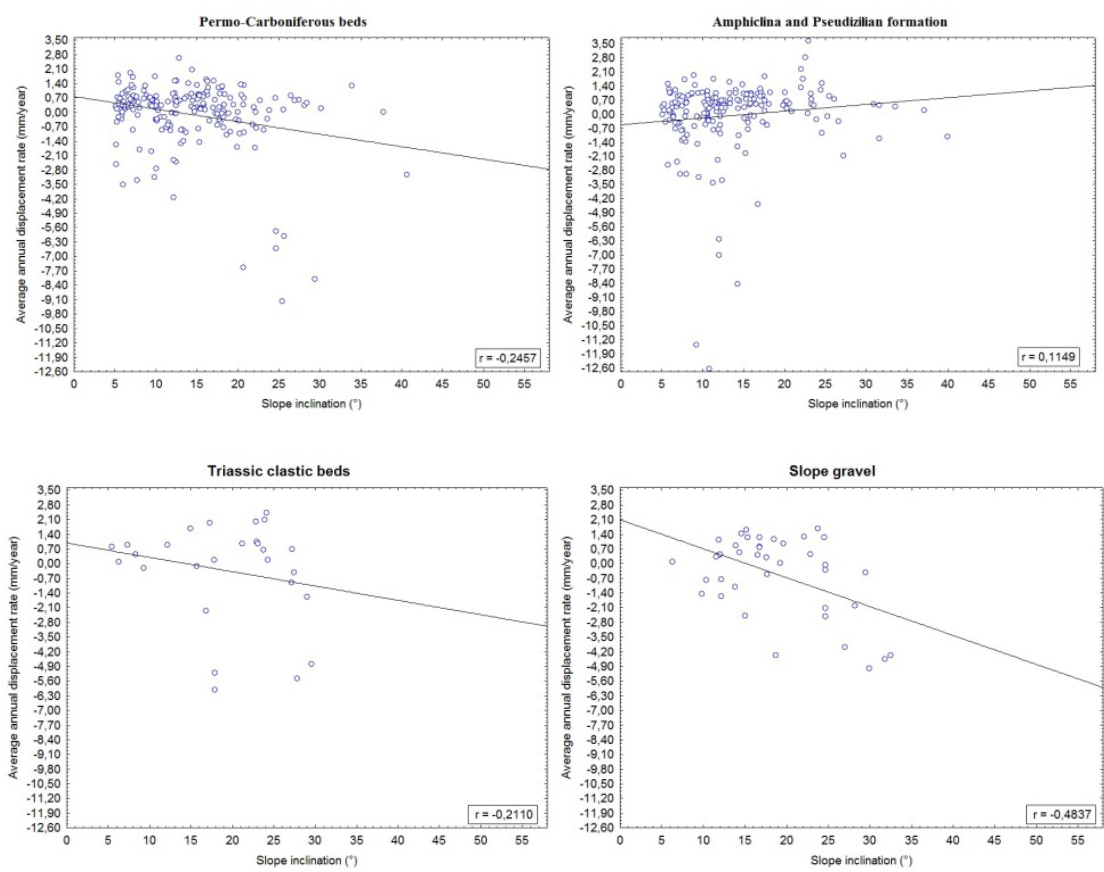

Figure 3: Correlations between average annual displacement rates of PS and slope inclination for four different lithological units.

inclination, although some indications exist. On a general scale there is usually a high variation of PS velocities, even within small zones or areas, which is most probably a consequence of a very rugged terrain (Škofjeloško-Cerkljansko hills) where the lithology and slope inclination change rapidly in space. Thus, based on the analysis of the correlation values of the average annual velocities and slope inclinations, we can conclude that the permanent scatterers should be regarded individually or as clusters spread over limited areas as these have more uniform terrain characteristic. Within the entire group of permanent scatterers, we defined small homogeneous clusters of PS located in the areas above Cerkno, Čeplez and Planina (A, B, C respectively in Fig. 1b). In those areas the average annual velocities of PS are faster than $-2 \mathrm{~mm} /$ year and with a constant downslope movement trend. According to Colesanti and Wasowski [21], Righini et al. [22] the velocities faster than $-2 \mathrm{~mm} /$ year can be associated with the processes of slope creeping. In the case of the three areas field observations gave evidence of previously occurred landslides and cracks on houses. Areas of observed past landslides are located close to PS. The majority of landslides occurred on Amphiclina and Pseudizilian formation, Permo-Carboniferous beds, Triassic clastic rocks and gravel. These visual indicators strongly support the suspicion of existence of potential slope creeping areas that were defined solely on PS data. Persistent scatterers located on lithological units that are highly susceptible to landsliding (Amphiclina and Pseudizilian beds, Permo-Carboniferous beds and 
rubble) show the highest down-slope (negative) velocities. Where velocities exceed $-2 \mathrm{~mm} / \mathrm{yr}$ and slopes inclinations range between 9 and $30^{\circ}$, areas can be classified as potentially exposed to creeping process

\subsection{Elements at risk}

Elements at risk are all valued attributes threatened by the hazard (the landslide or the creeping) and may include structures, land, resources, social and physical infrastructure productive and non-productive activities, environmental qualities, life and physical and mental wellbeing [13]. Some of these attributes are quantifiable, some can be expressed in economic terms while others defy ready quantification. The step "Evaluation of elements at risk" is mainly independent of the type of risk considered since it concerns the collection and use of information such as the cost of a building and its occupancy rate. Such information expresses the level of exposure, defined in natural hazard risk assessments by the characteristics of the population and physical environment at risk. In the creeping zones (Fig. 1) elements at risk are residential buildings and population. Actually, these three areas are small rural settlements that except for roads and water supply system have no social infrastructure (Table 1). The data in Table 1 show that in reality in potential slope creeping areas (settlements) there are several types of buildings. In the analysis we only consider residential houses as inhabitants represent the most vulnerable elements.

Table 1: $\quad$ Population and houses per settlement located on potential creeping zones in the western part of Škofjeloško-Cerkljansko hills.

\begin{tabular}{lcccc}
\hline Settlement & $\begin{array}{c}\text { Surface area } \\
\left(\mathrm{km}^{2}\right)\end{array}$ & $\begin{array}{c}\text { Residential } \\
\text { houses }\end{array}$ & Population & $\begin{array}{c}\text { Other buildings } \\
\text { (stables, hayracks) }\end{array}$ \\
\hline above Cerkno & 3.04 & 107 & 100 & 196 \\
Planina & 0.51 & 45 & 127 & 57 \\
Čeplez & 0.36 & 17 & 57 & 36 \\
\hline Total & 3.91 & 169 & 284 & 289 \\
\hline
\end{tabular}

Due to the lack of data an integrated approach to identify risk estimation as it is suggested by several researches $[13,23]$ was not possible. Based on available data of buildings [17] and data on population (only number of inhabitants per house) the populated areas were overlaid with the susceptibility map. The proportion of exposed residential buildings and population are shown in Table 2.

The results of the hazard analysis showed that majority of population in area above Cerkno and Planina live on very high landslide hazardous areas (Table 2). In the case of Planina 118 inhabitants or almost $93 \%$ of population live on very exposed areas while above Cerkno 140 or $48 \%$. 53 inhabitants or $92 \%$ of population in settlement Čeplez live on the areas where landslides pose at least a moderately small hazard. Among all three defined areas inhabitants of Planina settlement are the most exposed to landslide occurrence, followed by inhabitants 
Table 2: Distribution of residential houses and population according to eight landslide hazard classes for each settlements separately.

\begin{tabular}{lcccccc}
\hline Hazard Class & \multicolumn{2}{c}{ above Cerkno } & \multicolumn{2}{c}{ Planina } & \multicolumn{2}{c}{ Ceplez } \\
\hline & Houses & Population & Houses & Population & Houses & Population \\
\hline Very small & - & - & - & - & - & - \\
Small & - & - & - & - & - & - \\
Relatively small & - & - & - & - & - & - \\
Moderately small & 17 & 16 & 5 & 6 & 44 & 53 \\
Moderately high & 76 & 58 & 4 & 3 & - & - \\
Relatively high & - & - & - & - & - & - \\
High & 67 & 75 & - & - & - & - \\
Very high & 139 & 140 & 93 & 118 & 9 & 4 \\
\hline
\end{tabular}

of Cerkno and Čeplez settlements respectively. Interestingly, on all areas there are no populated buildings on areas with a small landslide hazard.

\section{Conclusions}

During the past two decades, the use of PSI for monitoring slow slope movements has been applied worldwide. In this paper, we defined hazard areas in the western part of the Škofjeloško Cerkljansko hills in central Slovenia, where landslide could occur as a consequence of present creeping processes that was detected using PSI.

The results show that the described technique is suitable as a complementary method to the conventional methods for landslide mapping. The analyses indicate that lithological units predefine the susceptibility to creeping. Despite this indication, the success of the technique depends also on the typology of landslides, their related kinematics, and the quality of PS. The PSI method is suitable for assessing the temporal evolution of slow and extremely slow landslides with constant deformation velocities, hereafter called slope creep. Thanks to the high PS density in some smaller areas within the broader study area it was possible to identify three areas with a constant deformation (area above Cerkno, Planina and Čeplez). On those areas, the analysis of average annual creeping rates revealed that lithology and slope inclination are among the key precondition factors for the occurrence of the slope creeping process.

Investigation of landslide hazard and risk is a complex undertaking and may include different approaches that depend on characteristic of available datasets. In order to conduct a more detailed study of potential risk at aforementioned areas the datasets of inhabited houses were cross-analysed with the landslide hazard map. In two of three settlements, the majority of the population live in hazardous areas while the most exposed to landslide occurrence are inhabitants of Planina settlement. 


\section{References}

[1] Zillman, J., The physical impact of disaster. In: J. Ingleton (Ed), Natural Disaster management. Tudor Rose Holdings Ltd., Leicester, pp. 320, 1999.

[2] Shuster, R.L. and Fleming, W.F., Economic losses and fatalities due to landslides. Bulletin of the Association of Engineering Geologists, XXIII (1), pp. 11-28, 1986.

[3] SORS, Statistical Office of the Republic of Slovenia, Ljubljana, 2011.

[4] Fell, R., Hungr, O., Leoroueil, S. and Riemer, W., Keynote LectureGeotechnical engineering of the stability of natural slopes and cuts and fills. GeoEng 2000, An international Conference on Geotechnical \& Geological Engineering, Melbourne, Australia, Invited Papers and Extended Abstracts + CD, Techomic Publishing Company, Lancaster, 1, pp. 21-120, 2000.

[5] Terlien, M.T.J., The determination of statistical and deterministic hydrological landslide-triggering thresholds. Environ. Geol, 35/2-3, pp. 124-130, 1998.

[6] Vulliet L., Modelling creeping slopes. Rivista Italiana di Geotecnica, 23/1, pp. 71-76, 1999.

[7] Komac, M., Napoved verjetnosti pojavljanja plazov z analizo satelitskih in drugih prostorskih podatkov. Ljubljana, Geološki zavod Slovenije, pp. 232, 2005.

[8] Ferretti, A., Prati, C. and Rocca, F., Nonlinear subsidence rate estimation using permanent scatterers in differential SAR interferometry. IEEE Trans. On Geosci. Remote Sensing, 38/5, pp. 2202-2212, 2000.

[9] Colesanti, C., Ferretti, A., Prati, C. and Rocca, F. 2003, Monitoring landslides and tectonic motion with the Permanent Scatterers technique. Engineering Geology, 68/1-2, pp, 3-14, 2003.

[10] Canuti, P., Casagli, N., Ermini, L., Fanti, R. and Farina, P., Landslide activity as a geoindicator in Italy: significance and new perspectives from remote sensing. Environ. Geol., 45, 907-919, 2004.

[11] Colesanti, C. and Wasowski, J., Satellite SAR Interferometry for Wide-area Slope Hazard Detection and Site-specific Monitoring of Slow Landslide. In: Landslides: Evaluation and Stabilization. Editors: Lacerda, Ehrlich, Fontoura, Sayo. Taylor and Francis Group, London, pp. 795-802, 2004.

[12] Hilley, G. E., Burgbman, R., Ferretti, A., Novali, F. and Rocca, F., Dynamics of slow moving landslides from Permanent Scatterer Analysis. Science, 304, pp. 1952-1955, 2004.

[13] Crozier, M.J. and Glade, T., Landslide hazard and risk: Issues, Concepts and Approach. In: Glade, T., Anderson, M. and M. Crozier (Eds): Landslide hazard and risk. Wiley, Chichester, pp. 1-40, 2005.

[14] Hungr, O., Evans, S.G., Bovis, M. and Hutchinson, J.N., Review of the classification of landslides of the flow type. Environmental and Engineering Geoscience, 7, pp. 221-238, 2001.

[15] Ferretti, A., Prati, C. and Rocca, F., Permanent scatterers in SAR interferometry. In: Proc. Int. Geosci. Remote Sensing Symp. Hamburg, pp. 1528-1530, 1999. 
[16] Farina, P., Colombo, D., Fumagalli, A., Marks, F. and Moretti, S., Permanent Scatterers for landslide investigations: outcomes from the ESASLAM project. Engineering Geology, 88, pp. 200-217, 2006.

[17] GURS, The Surveying and mapping authority of the republic Slovenia. Datasets from database of cadastral, 2011.

[18] Meisina, C., Zucca, F., Conconi, F., Verri, F., Fossati, D., Ceriani, M. and Allievi, J., Use of Permanent Scatterers technique for large-scale mass movement investigation. Quaternary International, 171-172, pp. 90-107, 2007.

[19] Komac, M., A landslide susceptibility model using the analytical hierarchy process method and multivariate statistics in perialpine Slovenia. Geomorphology, 74, pp. 17-28, 2006.

[20] Turner, A. K., Schuster, R. L. (eds.), Landslides: Investigation and mitigation. National Research Council, Transportation Research Board Special Report, Washington D.C., pp. 247, 1996.

[21] Colesanti, C. and Wasowski, J., Investigating landslides with space-borne Synthetic Aperture Radar (SAR) interferometry. Engineering Geology, 88, pp. 173-199, 2006.

[22] Righini, G., Del Ventisette, C., Constantini, M., Malvarosa, F. and Minati, F., Spaceborne SAR analysis for landslides mapping in the framework of the Preview project. In: Sassa, K., Canuti, P. (eds) Landslides - disaster risk reduction. Springer, Berlin, pp. 299-301, 2009.

[23] Roberts, W.J., Slope risk assessment and management. In A.K. Turner and R.L. Schuster (Eds), Landslide Society. The Association of Environmental and Engineering Geologist, Vail, Colorado, June 3-8, 2007, pp. 319-345, 2007. 